\title{
The Curious History of Trade Union Law Andrew Hodge*
}

\section{Clarity of underlying principle}

Since 1970 the pace and scale of change in the field of collective labour law have been remarkable, and it seems likely that this process of reform will continue. ${ }^{1}$ The 1980s have seen a number of important enactments which seem to reflect a radical view of collective labour relations. ${ }^{2}$ Sit John Wood has pointed out that, in this difficult and fast changing legal environment, it is important to achieve "clarity of underlying principle"3 3 both in our analysis of existing law and in our efforts to predict future developments.

It may be that the search for underlying principle requires some examination of the lessons of history. Labour legislation and the arguments that have surrounded it have had an important influence on our social, economic and political history. Should the law be used to underline or to dilute managerial prerogative? Should it be used to encourage or restrain the organisation of workers into trade unions?

Some of our most respected labour law commentators might argue that there is a sense in which both of the above questions are irrelevant, or even that it is inappropriate even to ask them. The traditional approach to the problems of industrial relations emphasises or even assumes that this specialised and vexed branch of human relations should not be interfered with by the law. ${ }^{4}$ In a democratic society where it is believed that state intervention should be avoided unless it is demonstrably necessary, this is clearly an important approach which recognises the limits of the law. It is equally clear, however, that Parliament and the courts have not adopted the traditional "abstentionist" view in practice. In particular, Parliament has intervened in collective labour relations on a regular basis since the $1970 \mathrm{~s} .{ }^{5}$

The history of collective labour law might reveal little more than the misguided or even malicious folly of Parliament in ignoring the abstentionist prescription, or,

*Of the School of Law, University of Buckingham.

1. During the $1989-90$ parliamentary session it seems likely that the Government will introduce a Bill to abolish the pre-entry closed shop. It is also possible that measures will be taken to restrain unofficial or "wildcat" strikes especially those which occur in essential services.

2. Viz., the Employment Acts, 1980, 1982 and 1988 and the Trade Union Act 1984,

3. Wood, "The Collective Will and the Law" (1988) 17 I.L.F. 1.

4. See, e.g., Wedderburn, The Worker and the Law (1971), p.1; cf. Howarth, (1988) 17 I.L.7. 11.

5. See, e.g. Wedderburn, supra n.4; $f$. Kahn Freund, (1974) 3 I.L.7. 186. 
more accurately, the lack of a prescription. Certainly, that might help to explain the sometimes fraught state of the law and of relations between governments of all political persuasions and the trade unions, particularly over the last 25 years.

But history may be a source of other lessons and other views. It might, for example, point towards other considerations, perhaps non-industrial, which seem to Parliament to have called for legislation. If it is accepted that the state has perceived such a need in the past it is very possible that it will do so again in the future. If that is so, it is important to identify and analyse the conditioning factors that operate on the legislative mind, and to see if any pattern emerges which might help to explain the curious history of collective labour law.

\section{The virtue of abstention and the vice of legalism}

To focus on the concerns of the state about collective labour relations is to challenge the traditional view which calls for their autonomy from the ordinary legal process. This traditional view requires a little further explanation. Put very simply, the argument is as follows.

Employment is a complex relationship which is only inadequately depicted by the legal device of the 'contract of employment'. While the law of contract in its classical form emphasises individual responsibility and the exchange of resources through a freely arrived at bargain, the exchange of labour for wages is a very different kind of process. Here the idea of a free bargain is misleading because of extreme inequality of bargaining power as between employer and employee. While the employer typically represents considerable resources of capital, enterprise and administration, the employee often can only represent his own strength and skill. Generally speaking, these may be obtained by the employer elsewhere unless there is a severe labour shortage in the relevant industry or area. Thus the employer is probably able to say to the employee: "These are the terms of my offer of employment, take them or leave them." Even at this early stage in their relationship there is a very clear disparity of economic power and it is this imbalance that dominates employment throughout. It is a situation that does not rest easily within the conceptual framework of the bargain or within its legal manifestation, the law of contract. So, at this most basic level of labour relations, the law is thought to be out of touch with reality. For example, Kahn Freund has suggested that the employment relationship is really a command in the disguise of a bargain. ${ }^{6}$

What is the solution to this central problem of inequality of bargaining power? Broadly speaking two quite different ways of approaching the problem might be suggested.

First, the state, in order to protect the public interest, might intervene to redress the balance of the employment relationship. It might mitigate the effects of inequality of bargaining power by withdrawing the right to bargain at all. It could 
define the respective rights and obligations of employer and employee in a way which leaves no room for oppression. ${ }^{7}$ But it is possible that the state would have to do this through the legal process which, it is suggested, is inadequate to the task.

The inadequacy of the legal system in this respect, and especially that of the courts, has been explained in a variety of ways ranging from its sheer ignorance of the relevant issues to class prejudice ${ }^{8}$ and the suggestion that English law is handicapped by an obsession with the power and the rights of the individual. ${ }^{9}$ As such, law as we now know it does not offer a viable solution to the problem of inequality of bargaining power. ${ }^{10}$ In any event, the sheer scale of state intervention that would be required would tend towards the totalitarian.

The traditional "abstentionist" school prefers a second and radically different approach. Workers can mitigate the consequences of their lack of power as individuals by combining into trade unions which will protect their collective interests. At its most effective, this would unite a given workforce into a monolithic factor of production with which the employer would have to bargain. ${ }^{11}$ But even here, it is argued, the law can do great damage because it has always been hostile to the necessary process of combination and the abstentionist can draw upon plenty of historical evidence to support this view. ${ }^{12}$ Ideally, the law should keep its distance from trade union organisation and from the process of collective bargaining. There is an appropriate role for the law, but it is essentially neutral supporting and guaranteeing an independent system of self-regulation rather than interfering with it or attempting to assume its functions. ${ }^{13}$

\section{The public interest and the law}

Since the 1860s Parliament has paid periodic lip-service to the 'virtue' of abstentionism. ${ }^{14}$ But actions speak louder than words, and the statute books reveal an addiction to the 'vice' of legislation. ${ }^{15}$ To be fair, some of it seems to have been intended to support the system of collective bargaining by providing facilities for information and conciliation or by enhancing the organisational rights of trade unions. ${ }^{16}$ But there are other enactments which go or have gone to the very

7. This is reflected in what might be called the "pre-contractual" history of labour law when all "employment relationships" were governed by statute and the coercive powers of the Justices of the Peace.

8. Griffith, The Politios of the fudiciany (1981), p.185 et seq..

9. See Wedderburn, (1988) 17 I.L.F. 1.

10. However, the law has moved in this direction to the extent that, where a contract of employment has existed for a certain time, statutory rights attach to it, irrespective of the express or implied intentions of the parties, e.g. the right to redundancy payments and the right not to be unfairly dismissed.

11. The argument for trade unionism is put with some force by the U.S. Supreme Court in American Steel Foundries v. Tri-City Central Trades Council 257 U.S. 184 (1921).

12. See the Combination Acts 1799 and 1800 and, e.g., Homby v. Close (1867) L.R. 2 Q.B. 153.

13. Arguably, this is achieved by the kind of legislation referred to in $n .10$ supra.

14. See the remarks in favour of the policy of collective laissez faire made by the Royal Commission on Trade Unions in its 1869 report.

15. Especially those of the last twenty years.

16. See, e.g., Industrial Relations Act 1971 and Trade Union and Labour Relations Act 1974. 
substance of industrial relations by attempting to influence trade union government, to formalise collective bargaining and bring it within the jurisdiction of the courts or to restrain collective industrial action. ${ }^{17}$ Obviously, the vicious path of legalism has had its attractions. Why?

One of the many functions of Parliament is to identify what it is that the public interest requires and to legislate accordingly. But what does the "public interest" mean? It cannot be identified scientifically; it is a matter of perception. At any given time the most important perception in legal terms is that of the political party that governs through a majority in the House of Commons. What a government calls the public interest is a matter of political preference underwritten by the electorate, rather than of empirical research. The process of identifying and legislating for the public interest is inherently contentious.

Arguments about law and policy do not all take place within the strict constitutional framework, to the extent that such a thing exists. The proceedings of the House of Commons and the hustings are only the most obvious examples of democracy at work. Many of the most compelling arguments about legislation result from less formal but equally influential encounters between government and sectional interests that may be affected by any change in the law. The Lord Chancellor's recent proposals concerning the administration of justice clearly go to the interests of the legal professions who have clearly formed a view upon them. These views and counter-proposals are expressed as representing the public interest but it is not entirely coincidental that they also amount to a defence of existing rights, privileges and interests which are entirely sectional. Similar forces are probably at work within the legislative process on a daily basis though perhaps less publicly than in the case of reform of the legal professions. Like those professions, organised capital and organised labour represent powerful though perhaps wider sectional interests and there is a sense in which their historical and current predicament is comparable to that of contemporary lawyers. Their struggle has been for the principle of self-regulation which, to them, serves the public interest which inevitably amounts to their own subjective perception of it. Government and Parliament may have a rather different view, again probably subjective but perhaps determined in the light of wider considerations or on the advice of expert bodies. The crucial legal and constitutional question is what happens when conflicting perceptions collide.

The dynamic and inherently controversial relationship between the "public interest" as identified by Parliament and as identified by narrower sectional interests is often fraught with difficulty and where the relevant sectional interest has enormous power at its disposal the potential for political and perhaps constitutional crisis is clear. The argument about how much power trade unions really have has raged for many years. ${ }^{18}$ The 'truth' about this seems to be very

17. See Industrial Relations Act 1971 and, although they are clearly not intended to formalise collective bargaining, the Employment Acts 1980, 1982 and 1988 and the Trade Union Act 1984.

18. For a summary of some of these arguments see Arnold, The Unions (1981), passim. 
elusive. Again, perception is all important and there are sections of the public who believe that the trade union movement and the process of collective bargaining have the potential to affect their lives very deeply and they expect the law to take a view - to encourage the process, to formalise it or restrain it as circumstances appear to them to dictate. These concerns are obviously of interest to Parliament.

Perhaps as important as the idea of abstentionism is the reality of government and the aspiration that it should be conducted in the wider public interest. The reality and the hope may have to be balanced against the technical logic of abstention and self-regulation. The delicate and sometimes disastrous relationship between the state and the sectional interests that are relevant to the process of collective bargaining may be as instructive in terms of underlying principle as the more specific relationship between capital and labour. Collective bargaining and industrial relations generally cannot realistically be treated as an entirely private process because they have such wide ranging effects on society as a whole. The law is bound to reflect this. ${ }^{19}$

For present purposes, this historical survey focuses on the relatively narrow issue of the relationship between the state and the trade union movement and the development of the trade union law which reflects and influences that relationship. This is because the whole system of collective bargaining depends upon the existence and viability of representative and effective trade unions. The development of trade union law must be symptomatic of the wider concerns of the state and its perception of the public interest.

\section{The history of the relationship between trade unions and the state}

Having explored the idea that the constitutional and political relationships between sectional interests and the state are as important as the economic relationships between those interests, it is time to test the idea against the reality of the history of trade union law. The exercise should be approached with two considerations firmly in mind: first, the extent to which the law has recognised the importance of the relationship between trade unions and the state; secondly, the ways in which it has attempted to regulate that relationship. For these purposes, the development of trade union law can be divided into a number of distinct phases each of which reflects a change in the nature of the relationship between labour and the law.

\section{Phase I - fear and prohibition}

The French Revolution of 1789 caused a wave of paranoia to sweep over the ruling classes of Europe - Great Britain was no exception. Indeed, there was a sense in which Britain was especially vulnerable to the threat of revolution because of the scale of economic transformation that it faced in agriculture and industry which were of a kind that is often accompanied by social unrest. Parliament

19. Cf. Jenkins and Sherman, Collective Bargaining (1977), ch.1. 
responded to the threat of political upheaval through repressive measures designed to prohibit any kind of non-state-sponsored collective action. The Combination Acts of 1799 and 1800 were intended to prohibit a wide range of organisations. They are chiefly remembered for their effect on the infant trade union movement. ${ }^{20}$

The Acts may be seen as a refusal to recognise any significance in the concept of organised labour, but this view is difficult to sustain because if trade unions were not thought to represent a threat, there would have been little point in prohibiting them. It is more likely that the state perceived them as a threat to the established economic order, and therefore as a threat to existing political authority. The Combination Acts were a crude attempt to hold that threat in abeyance. The important point to notice is the perception of that threat.

In 1824 the Acts were repealed, but this did not result from any change in the perception of threat, nor from a sudden outbreak of liberalism. ${ }^{21}$ There was no intention to encourage the unrestricted organisation of labour. In fact, the Act of 1824 was probably little more than an alternative technique of repression, based on the theory that trade unions were popular precisely because they were banned and somehow mysterious. It was hoped that the end of prohibition would cause the 'forbidden' fruit to wither. ${ }^{22}$ Parliament retained its apparent belief in a threat to established order - the critical relationship between government and sectional interest was recognised and the intention to neutralise that threat remained. All that had changed was the preferred technique of repression. In any event, industrial action remained legally difficult. There was no real evidence of liberalism. In fact 1824 saw an outbreak of militancy among the workforce and 1825 saw further legislation which created new and very broad criminal offences in respect of industrial action. ${ }^{23}$

The criminal law was not the only hazard facing trade unions during this early phase. The civil courts ensured that even if it was no longer illegal to belong to a trade union, the unions themselves would face serious organisational difficulties. Traditionally, trade unions have always seen themselves as unincorporated associations - loose, voluntary organisations with minimum legal content beyond the contract of membership embodied in the rulebook. ${ }^{24}$ Due to the nature and purpose of the union, it was inevitable that the contract would require some submersion of individual rights in the interests of the whole. Of course, this had the effect of restraining individual freedom of contract. The courts regarded this as an unlawful restraint of trade and consequently held that the union rulebook was unenforceable. ${ }^{25}$ It may be that the courts took this view because of their

20. Pelling, A History of British Trade Unionism 3rd ed. (1976), pp.25-29.

21. Combination Laws Repeal Act 1824.

22. Pelling, supra n.20, pp.29-32.

23. Combination Laws Repeal Amendment Act 1825.

24. See s.,2(1) Trade Union and Labour Relations Act 1974 though, practically speaking, this may have been superseded by more recent legislative developments.

25. See Homby v. Close, supra n.12. 
supposed obsession with individual freedom. It is equally possible that they saw the common law of restraint of trade as a means of minimising the perceived threat to established order by making union rules unenforceable in the hope that the unions themselves would dissolve into internal anarchy.

So long as trade unions remained simple bodies, bound together by a loyalty born from adversity or sponsored by wealthy philanthropists and committed to social change, ${ }^{26}$ this legal technicality may have presented few problems. However, the growth of less radical but more sophisticated craft unions in the middle of the 19th century saw an increase in the complexity of union government. ${ }^{27}$ The "New Model" unions also emphasised the provision of friendly society benefits - a system of organised saving which did not indicate a commitment to the destruction of civilisation as it was then known. Superficially, these were not threatening developments. Indeed, so far as the establishment was concerned, they must have represented a considerable improvement upon the syndicalism of earlier years. "New Model" unionism involved trade union officials in the administration of large sums of money. The unenforceable character of union rules did not help them, and this represented one of their most serious grievances.

At the same time, the influence of trade unions on the economy also grew. They succeeded in organising the "aristocracy of labour" - the railwaymen, the engineers and other groups of workers whose co-operation was vital to continuing national prosperity, and who had an interest in it. The representatives of the state could be forgiven for thinking that the threat of organised labour was diminishing. Instead, it was in the process of assimilating itself into the complex system of sectional and national interests that seem to be at the core of British government. Can it be a coincidence that it was at this stage, at the end of the $1860 \mathrm{~s}$, that government began to take account of this change of atmosphere and to listen to the trade union movement?

\section{Phase II - recognition and tolerance}

Paradoxically, the problems of mid-19th century trade unionism came to the attention of government because of an outbreak of industrial violence in Sheffield. In 1867, a Royal Commission was instructed to examine the issues. ${ }^{28}$ Note has already been taken of some of its conclusions, which seem to have been based on the principle of laissez faire or economic freedom.

The apparent permanence and considerable economic power of the emergent trade union movement concentrated government minds on the need to remove some of the legal disabilities resulting from judicial decisions like that in Hornby v. Close ${ }^{29}$ Both the state and the sectional interest of organised labour had an interest in achieving some kind of modus vivendi.

26. E.g., Robert Owen's Grand National Consolidated Trade Union of the 1830s.

27. Pelling, supra n.20, ch.4.

28. Royal Commission on Trade Unions 1867-69.

29. See, supra, n.25. 
The legislative result of this change of atmosphere is to be found in the Trade Union Acts of $1871^{30}$ and $1876^{31}$ which were designed principally to mitigate the common law of restraint of trade. The effect of the 1871 Act was to bring some kinds of trade union rules within the protection of the ordinary law of contract by exempting them from the law of restraint of trade and allowing them to be enforced in the courts. ${ }^{32}$ However, the exemption was qualified in that it would not apply to any rule designed to oblige the member to break the contract of service that bound him to his employer. ${ }^{33}$ The Act of 1871 also introduced a system of voluntary registration for trade unions. Those whose rules met certain formal requirements could register as friendly societies under an existing statutory scheme. ${ }^{34}$ Both the unions and the state gained advantages here. The unions acquired various fiscal advantages which assisted them in administration of financial benefits, while government acquired a valuable source of information about a powerful sectional interest, and some input into its affairs. ${ }^{35}$ This may have indicated some recognition by Parliament that trade unions were permanent and powerful. It also indicated a willingness to do business with them. Economic and political developments, not least the extension of the franchise to the very people whom the unions existed to represent, made the need for some kind of relationship pressing. ${ }^{36}$

The Trade Union Act 1871 was the basis of the law of organised labour for a century. ${ }^{37}$ But, as Folke Schmidt points out, government acceptance of the fact of trade unionism should not be seen as encouragement of it.

"The laws on industrial action enacted in the 100 years between the Trade Unions Act 1871 and the Industrial Relations Act 1971 were based upon the idea of toleration. The fact that the trade unions were protected did not mean that they were loved by those in the establishment; certainly, the judges were critical and wanted to restore the law to what it was before $1871 ., 38$

It is certainly true that between 1871 and about 1910 , the courts used the legislation of the 1870 s in surprising ways. For example, the withdrawal of criminal conspiracy through the Conspiracy and Protection of Property Act 1875 was without prejudice to the judicial discovery of the tort of conspiracy in Quinn v.

30. 34-35 Victoria c.31

31. $39-40$ Victoria c. 22 .

32. Trade Union Act 1871, section 3.

33. Section 4.

34. Section 6.

35. In the sense that there were formal criteria for the validity of the rules. In the absence of such validity, the union could not register: see section 14 and Schedule 1.

36. See Representation of the People Act 1867.

37. Until its repeal by the Industrial Relations Act 1971.

38. Schmidt, (1974) 3 I.L.7. 69. 
Leatham a few years later. ${ }^{39}$ Perhaps even more interesting was the attitude of the courts to trade unions as institutions at the beginning of the 20th century.

A number of distinguished scholars have doubted the importance of the supposedly sterile issue of the organisational status of trade unions, perhaps because it bears the stigma of legalistic abstraction. ${ }^{40}$ However, the ways in which Parliament and the courts have defined and analysed their legal status may provide a useful indication of more general attitudes. There is a clear difference between seeing trade unions as loose, voluntary associations with minimum legal content and seeing them as sophisticated statutory or corporate bodies, endowed with valuable rights and encumbered with serious obligations both to their members, and to the rest of the world.

This issue was addressed by the House of Lords in the famous TaffVale Railmay case. ${ }^{41}$ The crucial question was whether a trade union, registered under the 1871 Act, could sue and be sued as an organisation in its own name, in the same way as a corporation. The traditional view was that this was not possible, because unions were seen as simple unincorporated associations with no separate legal personality. ${ }^{42}$ In the course of argument before the House of Lords, counsel for the defendant trade unions submitted that:
"A trade union is not a corporation. It is like a club, not a legal entity: and there are good reasons for this view. If the society can be sued as such, the funds intended for the benefit of widows and orphans can be reached and perhaps exhausted in consequence of improper and illegal acts of the society's officers." 43

Obviously, this statement accords with the traditional view that the union could not be seen as a legal entity. Its only legal content was thought to be the contractual nature of its rules. That was the basis of the decision in Hormby v. Close ${ }^{44}$ and of the provisions of the 1871 Act. Lord Brampton, however, departed from this view and argued that the legislation of the 1870 s had elevated trade unions on to a more sophisticated legal plane. In his view, a registered trade union was a "newly created corporate body created by statute, distinct from the unincorporated trade unions consisting of many thousands of separate individuals." 45 Accordingly, a registered trade union, like a corporation, could sue and be sued in its own name. Its funds became available to satisfy judgment and to purge its contempt of court, and in many respects this is still good law.

39. [1901] A.C. 495; see also Temperton v. Russell [1893] 1 Q.B. 715 (trade union sponsored industrial action amounting to the tort of inducing a breach of contract) and 7. Lyons and Sons v. Wilkins [1896] 1 Ch. 811 (picketing amounting to the tort of nuisance.)

40. See Wedderburn, supra n.4.

41. Taff Vale Railway Co. v. Russell, supra n.39; of. Duke of Bedford v. Ellis [1893] A.C. 1.

43. [1901] A.C. 426 , at p.435.

44. Supra n.25.

45. [1901] A.C. 426 , at p. 442 . 
The significance of Lord Brampton's view became clearer nine years later in Amalgamated Society of Railway Servants v. Osborne. ${ }^{46}$ In this case, a registered union had decided to maintain a political fund to be financed through a levy on its members. Osborne, a member of the union, challenged the legality of the fund and of its purpose.

The House of Lords seized upon the notion that the registered union was a kind of statutory quasi-corporation and used it to assert a wide jurisdiction to review trade union rules and activities to ensure that they were consistent with the legislation. Lord Halsbury took the view that the Acts of 1871 and 1876 contained an exhaustive definition of permissible union conduct. ${ }^{47}$ Parliament, it seemed, had created a new species - the registered trade union - and had empowered it to represent its members in matters of labour relations. Its brief did not extend to any kind of political activity. The union was like any other corporate body, allowed to exist and function through privileges conceded to it by the state which retained the right to supervise and restrain its conduct through the courts. And just as the courts were entitled to restrain a corporation from any action ultra vires its charter, statute or memorandum of association, so they were entitled to prevent a registered union from acts not permitted by the Trade Union Acts. Lord Macnaghten summarised the argument:

"It is a broad and general principle that companies incorporated by statute for special purposes and societies, whether incorporated or not, which owe their status to an Act of Parliament, having their objects and powers defined thereby cannot apply their funds to any purpose foreign to the purposes for which they were not established or embark on any undertaking in which they were not intended by Parliament to be concerned." 48

Much of this has been dismissed as mere "Tory Law", an indication of establishment hostility towards organised labour. ${ }^{49}$ It is possible that Taff Vale and Osborne represent the consequences of the individualistic obsessions of the common law which make it incapable of constructing rational labour laws. That political preference, rather than legal reasoning, led to these decisions is now regarded as axiomatic. ${ }^{50}$ The $1880 \mathrm{~s}$ and 1890 s had seen the organisation of unskilled labour into trade unions, made militant by economic recession and more reminiscent of the syndicalist organisations of the 1820 s and 1830 s than of the craft unions whose interests had been vindicated in $1871 .{ }^{51}$ Also, the franchise was

46. A.S.R.S. v. Osborne [1910] A.C. 87.

47. Ibid., at p.92.

48. Ibid., at p. 94 .

49. Similar sentiments were expressed by trade unionists recently on the steps of the Royal Courts of Justice after they had heard the Court of Appeal decline to remove an injunction against a proposed national dock strike. A few days later the decision was reversed by the House of Lords.

50. See J. A. G. Griffith, supra n.8.

51. Pelling, supra n.20, ch.6. 
extended to the point of universal male suffrage. ${ }^{52}$ "Lib-Lab" and even "Labour" candidates had been elected to Parliament. ${ }^{53}$ This was the end of an era. Perhaps a conservative judiciary hoped to restrain its demise, or even to ease the transformation by restraining trade unions, to prevent them from becoming a sectional interest capable of challenging those equally sectional interests that were represented by the ruling establishment of the 19th century. However, in Osbome Lord Shaw counselled caution and urged that a sense of perspective was important in considering the true significance of the Trade Union Acts. He remarked that:

"Long before the statutes of 1871 and 1876 were enacted trade unions were things in being the general features of which were familiar to the public mind. They were associations of men bound together for common ends. Statutes did not set them up and speaking for myself, I have some hesitation in construing language of statutory recognition as a definition imposing such hard and fast restrictive limits as would cramp the natural developments of the living organism." 54

Apparently, Lord Shaw saw the Acts as an attempt to assist existing trade unions, not to establish them in a new form and then to regulate them through the legal system. His was the minority view. The orthodox view of these cases is that they represent the best possible reasons why the state and the law should keep their distance from the field of labour relations. It was in the House of Lords in the first decade of the 20th century that the seeds of doctrines of abstentionism and autonomy of Labour Law were sown.

Equally, these elderly and seemingly reactionary judgments and the quasi-corporate theory of labour organisation that they produced seem to contain the seeds of the notion that trade unions are far too important to be left to their own devices. The thoughts of Halsbury and Macnaghten are, perhaps, inherent in the controversial judgments of Lord Denning speaking 50,60, and 70 years later. ${ }^{55}$ The idea that there may be an ideal, defined legal relationship between organised labour and constitutional government is as central to the story of Labour Law in the second half of the 20th century as is the relationship between capital and labour. The battle lines of abstentionism and legalism had been drawn, but first there was a lull in the proceedings.

\section{Phase III - 1910-1960: a period of tranquillity}

At first sight, the period 1910 to about 1960 seems anything but tranquil. The relationship between government and organised labour developed in a variety of ways.

52. Representation of the People Act 1884.

53. Pelling, supra n.20, ch.6.

54. Osborne, supra n.46, at p.107.

55. See, e.g., Lee v. Showmens Guild of Great Britain [1952] 2 Q.B. 329; Breen v. Amalgamated Engineering Union [1972] 2 Q.B. 175, and Cheall v. A.P.E.X. [1983] Q.B. 126. 
In the first place, it is reasonably clear that the judicial view of trade unions was not wholly shared by Parliament, especially during the period of Liberal domination that lasted from 1906 until after World War I. The Trade Disputes Act of 1906 gave trade unions a wide immunity against any tortious liability that might arise from trade disputes, ${ }^{56}$ and to a large extent this neutralised the most obvious adverse effects of Quinn v. Leatham and Taff Vale. The Trade Disputes Act $1913^{57}$ mitigated Osborne by permitting the unions to maintain political funds. But although Parliament did much to mitigate the practical effects of these decisions, it did little to discredit the organisational theory of quasi-incorporation that made them possible. ${ }^{58}$ The concept of a concessionary relationship between the state and the trade unions, regulated through the courts, remained. It may be that Parliament simply acted to minimise the chance of conflict between labour and the law. There was an abstention from conflict rather than an abstention from legalism.

That is not to say that conflict was absent from this period, for during the 1920s the coal miners and transport workers emerged as the 'crack troops' of organised labour, confronting the government and its economic policies on a number of occasions between 1910 and 1926, most notably during the General Strike. During the strike the union movement showed, at the very least, that it had the potential to mobilise the interests of labour to paralyse the economy, though this potential was not actually realised in 1926. Soon afterwards, the Great Depression began to bite. Inevitably, the power of organised labour diminishes when demand for labour is flat. In 1927, the atmosphere of tentative collective laissez faire that had prevailed since the Trade Disputes Act 1906 changed. The Trade Disputes Act 1927 restricted the validity of the political fund by emphasising the rights of the individual over the interests of the collective entity. ${ }^{59}$ It also prohibited political strikes. ${ }^{60}$ The legal sub-structure of Taff Vale and Osborne was revived. Trade unions would be allowed to exist and to function provided that they restricted themselves to the conduct of industrial relations. ${ }^{61}$ However, the representatives of the state were wary of going too far down the road of regulation. The forces of labour had succeeded in creating a viable political party. At a time of instability in the party system, a radical attack on the unions might have swept the Labour Party into power. ${ }^{62}$

The two world wars in our period inevitably led to a great deal of social change. In particular, the relationship between trade unions and the state altered because

56. 6 Edward 7, c. 47.

57. 2-3 Geo. 5, c.30.

58. But see Trade Union Act 1913, section 1 of which limits the importance of the statutory objects specified in the 1871 Act. However, this was subject to section 2 which prohibited the Registrar from registering a union unless it was within the statutory objects.

59. Especially sections 2,3 , and 4 .

60. Section 1.

61. Subject to $\mathrm{n} .58$ supra.

62. The Labour Party formed governments in 1924 and 1929 but on neither occasion could it be said that it swept into office. 
of the imperative need for national unity. During both world wars, government assumed wide powers to direct the economy, to control labour and to suspend collective bargaining. ${ }^{63}$ The extent of regulation was enormous. In the circumstances, it is not surprising that organised labour was prepared to accept this. It is surprising that this co-operation broke down on so very few occasions. ${ }^{64}$

This new, very close relationship between government and trade unions was especially significant during World War II when trade unionists like Ernest Bevin became leading figures in the coalition government. They were able administrators and they could deliver the co-operation of their members. They were also able to demonstrate that a kind of socialism was viable during wartime, leading to an expectation that collectivism would be helpful during peacetime too. ${ }^{65}$ This period continued through to the election of the first independently viable Labour government in 1945 and, arguably, even beyond its final defeat in 1951. The Trade Disputes Act 1927 was repealed in 1946 so that the law returned to the collective laissez faire that had prevailed between 1906 and $1927 .{ }^{66}$ But, again, the system of collective Labour Law was not the subject of any radical overhaul. ${ }^{67}$ The spirit of Lord Halsbury still hovered and the seeds of doctrinal conflict remained. The conflict did not arise between 1945 and 1951 because, while trade unionists were in government, there was no need for fundamental disagreement between the sectional interest and that of the state. Also, on the economic front there was a very real sense in which the war was still being fought. The task of reconstruction was enormous. The drive for exports and simple need to feed, clothe and house the population were paramount.

Friendly and co-operative relations between the state and the trade unions continued through the early years of the Conservative government which took office in 1951. Senior ministers had worked with prominent trade unionists during the period of wartime coalition. Subject to the issue of nationalisation there was much common ground between them. ${ }^{68}$

It seems clear that, during this period, a relationship of some kind existed between government and trade unions, and that this was thought to be important and positive by both sides. Legally, it continued to rest upon the Trade Unions Act 1871 which could mean different things to different people, as the disagreement between Lords McNaghten and Shaw in Osborne shows. ${ }^{69}$ But the political climate and the personalities of the time made extensive legal regulation of trade unions,

63. In both 1915 and 1940 strikes and lockouts became criminal offences. During World War II, free collective bargaining was suspended and replaced with a system of compulsory arbitration.

64. E.g., the Kent miners strike of 1941 which was settled: see Wedderburn, supra, n.4, p.29.

65 . Some of the policies and proposals of the wartime coalition became the basis of a postwar political consensus.

66. Trade Disputes and Trade Unions Act 1946.

67. Indeed, the express purpose of the repeal was to restore "all enactments and rules of law" affected by the Trade Disputes Act 1927.

68. Pelling, supra n.20, pp.257-260.

69. See, supra, text pp.101, 102. 
through the 1871 Act or otherwise, unnecessary. But this period of tranquillity did not last.

\section{Phase IV - the 1960s: the beginning of conflict}

In the late $1950 \mathrm{~s}$ and early $1960 \mathrm{~s}$, British society began a fundamental reassessment of the role of trade unionism, at a time when society as a whole was in the process of change. The cost of the Second World War and the process of decolonisation had changed the ground rules of the British economy. The need for Britain to "pay its way" became a dominant political theme, and the control of living standards became the core of economic policy. ${ }^{70}$ Clearly, there was a tension between this theme and the need for trade unions to represent the rising aspirations of their members. While government developed a strong interest in the policy of pay restraint, the unions felt themselves to be obliged to oppose that policy for the benefit of their members and in order to preserve free collective bargaining. The relationship between the state and trade unions now contained a very basic and direct conflict of interest. Government believed that pay restraint was clearly in the national interest. Equally clearly, trade unions saw the imposition of pay restraint by the state as contrary to the interest of their members. This conflict dominated the atmosphere of the relationship, and its legal content, for the next 20 years.

During the late 1950 s and early 1960 s, however, government was reluctant to use the law as an instrument of its policy towards the unions. Certainly, there were judicial decisions which re-emphasised that trade unions, despite their 'privileges' were not 'above the law' and that there was a legal presumption against strikes. ${ }^{71}$ Nevertheless, Parliament attempted to avoid conflict and to promote co-operation by 'oiling the wheels' of the existing relationship, and drawing upon existing good will. The government set up a National Economic Development Council which drew its members from government, capital and organised labour and was chaired by the Chancellor of the Exchequer. ${ }^{72}$ Its function was, and still is, to identify obstacles to economic development and ways of overcoming them. This may be seen as a component of a new technique for the formulation of economic policy, relying upon negotiation between the state and the major economic interests.

To begin with, this technique was not conspicuously successful. It was difficult to build a consensus around the policy of pay restraint, which remained unpopular. Unfortunately, the validity of the whole exercise depended upon achieving such a consensus. ${ }^{73}$ Pay restraint was inimical to the most basic interests of organised labour and, to some extent, it was contrary to the interests of capital as well. Because of this diversity of interest, the Conservative governments of the late 1950 s and 1960 s were forced to adopt alternative policies. Interestingly, they did

70. E.g., Selwyn Lloyd's Pay Pause of 1962.

71. See, e.g., Lee v. Shommens Guild, supra n.55, and Thompson ES Co v. Deakin [1952] Ch.646.

72. Created under the auspices of the Chancellor of the Exchequer.

73. Pelling, supra n.68. 
not proceed along the course of legal regulation of collective bargaining. Instead, they were forced to rely upon short term fiscal and monetary adjustments as a way of managing demand and controlling the economy; again, without notable success.

The Labour Party returned to power in 1964, but their predecessor's problems remained. The crucial question was how to achieve export led economic growth. For the Wilson government, restraining consumption at home was only a part of the solution. The new administration also placed a great deal of faith in the modernisation and central planning of the economy. The basic concept of the NEDC was expanded and a new Department of Economic Affairs was created. Its influence was to rival that of the Treasury; its brief was to plan for and promote strong and sustainable economic growth. The co-operation of capital and of organised labour was plainly crucial to its success. It seems that trade unions were prepared to accept the desirability of planned economic growth in principle. In practice, there were serious difficulties. Financial problems, resulting partly from the instability of sterling, caused inflation. In an inflationary environment, it became very hard for union leaders to restrain the expectations of their members. $^{74}$

In the middle and late 1960 s there were serious national strikes among the railway workers, the dockers and the merchant seamen. Again, government did not choose to use the legal system to meet the problem. ${ }^{75}$ Instead, the search for informal consensus continued, albeit in a more public and perhaps desperate way than before. State intervention took the form of persuasion, emphasising that the national interest required restraint from sectional interests. Many trade union leaders sympathised with the core of what ministers were saying, but it remained difficult for them to reconcile the proposed sublimation of their members' interests with their basic function, the promotion of those interests. In short, those leaders were unable to deliver the co-operation of their members. ${ }^{76}$ The principle of abstentionism, and the loose organisational structure that it allowed unions to retain, meant that they could not be controlled - even by their own officials. The co-operative relationship between government, labour and capital began to crumble under the weight of spontaneous and unofficial industrial action. So did the government's economic policy.

In this climate, it is not surprising that policy-makers began to doubt the sense of collective laissez faire and co-operative economic planning, or at least their ability to exist together. To many, it seemed that a new, more formal set of relationships was needed: between labour and capital, and collective bargaining and the law. In some minds at least, thoughts of Taff Vale and Osborne revived. ${ }^{77}$

74. For an account of this period see Harold Wilson, The Labour Government 1964-1970 - A Personal Record, ch.l.

75. Subject to the Trade Disputes Act 1965 which had the relatively narrow purpose of overruling the controversial decision of the House of Lords in Rookes v. Rookes [1964] A.C. 1192.

76. See Pelling, supra n.20, pp.262-266.

77. See, e.g., $A$ Giants Strength (Inns of Court Conservative Association, 1958). 
A Royal Commission, chaired by Lord Donovan, reported its findings in $1968 .^{78}$ In its view, the complex relationships between labour and capital, collective bargaining and economic policy could only improve and stabilise if relations improved and stabilised on the shop floor. The views of union members were subverting the vital process of collective bargaining and turning it into the great imponderable of economic policy. Shop floor tensions were the source of unofficial industrial action which, in turn, was a cause of economic dislocation. Having identified the flaw in relations between competing economic interests and the national interest, the Donovan Commission had to recommend remedial action. The Commission reaffirmed the virtues of the policy of abstentionism and the inadequacy of legalism as an approach to industrial relations. However, it also proposed the enactment of Industrial Relations legislation which would formalise and strengthen collective bargaining. It was thought that government had a role, but that it should be value - neutral. It would not claim a controlling interest, but it would create machinery for the registration of collective agreements in the interests of consistency and certainty. It would also act as a source of information and advice. None of this was outside of the supposed 'tradition' of abstentionism. However, there were other proposals which contemplated a much more direct and legalistic relationship between the state and the unions. For example, it was proposed that union rules should conform with statutory standards - formal and substantive, and that union members should acquire the legal right not to be unfairly excluded or expelled from their union, as a corollary to the right not to be unfairly dismissed by an employer. These were legalistic proposals contemplating the development of organisational norms by the state, and their embodiment in the law. The Donovan Report is often cited as the central text of the abstentionist analysis, yet it can also be seen as a vindication of the legalistic view in Taff Vale and Osborme. The Commission was prepared to propose quite extensive legal regulation of collective bargaining, and of the trade unions themselves.

The trade union movement reacted to these proposals with considerable suspicion and some alarm at the prospect of legal involvement in collective bargaining, and in their own internal affairs. So far as they were concerned, the law should be used to underpin collective bargaining by guaranteeing minimum conditions of employment and the right to strike, but it should go no further than that. ${ }^{79}$

The government, convinced that a new approach was needed, published a White Paper entitled "In Place of Strife". ${ }^{80}$ Ostensibly, the document adopted the Donovan analysis, but it also proposed that the role of the law should be strengthened. The newly created office of Secretary of State for Employment and Productivity would carry with it a power to impose a conciliation pause before

78. Cmnd. 3623 .

79. For a more detailed summary of the principal recommendations and of trade union reactions to them see Balfour, Unions and the Lam (1973), ch.2.

80. Cmnd. 3888. 
unofficial industrial action. Trade unions would be obliged to ballot their members before sanctioning official action. New statutory duties would be enforceable by way of fines, through an Industrial Board.

"In Place of Strife" contemplated an enhanced role for government in the field of industrial relations. The aim seems to have been to use the law to modernise and plan collective bargaining in order to modernise and plan the economy. However, the proposals failed because of the inability of the Parliamentary Labour Party and of the Cabinet itself to unite around them. The unions were vehemently opposed to the creation of a new, more interventionist legal regime. The Labour Party was unable to overcome that opposition. In place of introducing legislation, Parliament was forced to accept a "solemn and binding" undertaking from the TUC that it would use its best endeavours to prevent or resolve unofficial strikes. It would not accept any legal intervention in the internal affairs of unions, nor any legal restraints upon their freedom of action. ${ }^{81}$

As Parliament was unable to act, government was forced to depend for the success of its policies upon the goodwill of a sectional interest. This was in stark contrast to the position in 1871 when trade unions had to rely upon Parliament to carve out their place in the legal system. For the first time it was possible to say that in the relationship between the state and organised labour, it was the sectional interest that had the upper hand. The economic and constitutional tensions that were contained in this development erupted into conflict in the decade that followed.

\section{Phase V - the 1970s: crisis and experiment}

When a new Conservative government took office in the summer of 1970, it saw itself as having received a clear mandate to use the law to reform industrial relations. There had been a 'legalistic' school within the Conservative Party throughout the 20th century. While in opposition, the Party had published an "alternative' to "In Place of Strife" entitled "Fair Deal at Work" ${ }^{82}$ Its recipe for reform contemplated a substantial injection of legal supervision of labour relations. While the unions continued to preach the creed of abstentionism, government became committed to the policy of legalism.

The Industrial Relations Act 1971 drew heavily upon "Fair Deal at Work" which was in turn influenced by the federal labour relations law of the United States. American labour law depends upon organised collective bargaining, and there is a sense in which Congress is responsible for its existence. However, the whole process and the trade unions themselves are subject to a wide range of legal obligations, and to the supervision of the National Labor Relations Board and the

81. For a first hand account of this period see Wilson, supra n.4, chs. 28-31. See also Balfour, supra n.79, ch.3. and Jenkins, The Battle of Downing Streat (1970).

82. Conservative Political Centre, 1968. 
Secretary of Labor. ${ }^{83}$ An atmosphere of economic and political crisis, a belief in legalism and the transatlantic influence - these were the conditioning factors that led to the Industrial Relations Act.

The provisions of the Act are discussed exhaustively elsewhere, but its major principles should be mentioned. ${ }^{84}$ As has been said, the Trade Union Act 1871 had created a system of voluntary registration of trade unions. The 1971 Act enhanced the importance of registration. A "union" that failed to register would not be a "trade union" at all for the purposes of the Act. Registration was not possible unless the union rules appeared to a Chief Registrar to be fair, responsible and democratic. If at any time the rules failed to meet the statutory criteria, the Chief Registrar could apply to the new National Industrial Relations Court for an order cancelling any existing registration. ${ }^{85}$ The significance of this new, stronger concept of registration is obvious. It meant that the state, through the Chief Registrar and the court, would have power over trade union government to an extent that was far greater than anything contemplated by the law, before or since.

The theme of legal intervention in the internal affairs of unions was repeated in a statutory right to membership or non-membership of a trade union. ${ }^{86}$ It was in the nature of a voluntary association that it had the right to regulate its own membership - this was a part of the culture of abstentionism. Similarly, the efficiency of collective bargaining was thought to depend upon solidarity, frequently enforced through Union Membership Agreements. The Act moved away from those principles. ${ }^{87}$ Many saw this as an attempt to impose the lawyer's conception of individual liberty upon organisations which, by their very nature, take a more collectivist view of freedom. Another effect of the 1971 Act was to give Labour Law its own distinctive legal system. Collective bargaining and industrial action were to be analysed by reference to a code of Unfair Industrial Practices, based on the Unfair Labor Practices of US labour law. ${ }^{88}$ These new concepts were to be applied through a system of Industrial Tribunals and a National Industrial Relations Court. ${ }^{89}$ The tribunals had existed since 1964, with very limited jurisdiction. The NIRC was an innovation. It was exclusively concerned with Labour Law and, like the Industrial Tribunals, was composed of a legally qualified chairman (in this case a High Court Judge) and two 'wingmen' with industrial relations experience. The court was of similar status to the High Court

83. See National Labor Relations Act 1935 as amended in 1947 and the Labor-Management Reporting and Disclosure Act 1959, 29 U.S.C. s.152 et seq..

84. See, e.g., R. Simpson and J. Wood, Industrial Relations and the 1971 Aat (1971) and, as a retrospective, Kahn Freund, (1974) 3 I.L.7. 186.

85. Industrial Relations Act 1971, Part IV.

86. Sections 5 and 6.

87. The Act abolishes the device of the pre-entry closed shop but permitted the adoption of the American device of the 'Agency shop': see sections 7 and 11-18.

88. Sections 54 and 55 of I.R.A. 1971; of. National Labor Relations Act 1935, 29 U.S.C. sections 158(a) 5,158 (d) et al..

89. I.R.A. 1971, Part VI. 
and had the right to imprison or fine for contempt of court - a power that it used to disastrous effect during its brief life. ${ }^{90}$

The Industrial Relations Act was a bold attempt to regularise and supervise the conduct of industrial relations. The role of law was increased, and an attempt was made to systematise it. The government took the view that it was responsible for economic policy and for the protection of the national interest. It also had the right to require that industrial relations be conducted in an efficient and orderly way. Law appeared to be the best way of ensuring that they were.

Although law, as an instrument of policy, can influence and harness processes and interests and can act as an umpire between them, it cannot define them. If a new system of law is to survive it must have the co-operation of those who are affected by it. Clearly, the required co-operation was not forthcoming from the trade union movement. The Industrial Relations Act failed because of organised opposition. This was largely passive. On the whole, the unions simply failed to acknowledge the Act's existence. ${ }^{91}$ There were a number of emotionally charged legal actions which brought the Act into disrepute. The state had committed itself to legalism and to offering a highly organised system of industrial relations. The offer was not only resoundingly rejected, it was never seriously considered. The Industrial Relations Act jeopardised relations between the government and the trades union movement, though there is evidence that the real objection was to the Act's legalism and not to the Conservative government itself. ${ }^{92}$

Between 1972 and 1974, the economy staggered from crisis to crisis. The price of oil increased dramatically, there was runaway inflation and a series of national strikes, culminating in the miners' strike of 1973-4. In February 1974, the Prime Minister sought a dissolution of Parliament and fought the ensuing general election on the emotive issue of "Who governs Britain?" By now, the electorate could be forgiven for thinking that no-one could govern without the consent of the unions. The Labour Party was able to form a minority government. One of its first measures was the repeal of the Industrial Relations Act. ${ }^{93}$ In October 1974, the new government was confirmed in office with a parliamentary majority of only 3 seats.

Through its own bitter experiences in the late 1960s, and those of the Conservatives, the Labour Party seems to have concluded that economic policy and pay restraint were only obtainable with the active co-operation of the unions. Legal regulation of collective bargaining was thought to be unworkable. Indeed, some Conservatives had also come around to this view. ${ }^{94}$ The relationship

90. See Churchman v. Joint Shop Stemards Committee [1972] 1 W.L.R. 1094. For a readable account of some of the difficult cases that arose from the Act, see Lord Denning, The Closing Chapter (1983), pp.164-177.

91. A colleague who taught a course for shop stewards in the early 1970 s found that many would turn their backs to her whenever the Act was mentioned.

92. See the reported remarks of Lord Carr in Arnold, supra n.18, pp.22 and 23.

93. Trade Union and Labour Relations Act 1974, s.1.

94. Young, One of $U_{s}$ (1989), pp.108-110. 
between government and the trade union movement had to be placed on a new footing. The Labour government approached the problem by emphasising the concept of partnership and inviting the union movement to participate in the creation and execution of economic policy. This approach was implemented through the novel device of the "Social Contract", an agreement by which the unions promised pay restraint in return for the adoption of socialist policies, legal guarantees of trade union independence and organisational rights and a code of minimum workers' rights. ${ }^{95}$ Symbolically, the Trade Union and Labour Relations Act 1974 provided that trade unions were not bodies corporate and that they were not to be treated as if they were. ${ }^{96}$ Thus, the ghosts of Taff Vale and Osbome were laid to rest, though some of their practical consequences remained.

A great deal of our modern Labour Law was created under the influence of the Social Contract. ${ }^{97}$ For a time, both government and labour were able to deliver their sides of the bargain. There was an absence of confrontation and inflation was brought under control, but by 1978 the flaws in the Social Contract became apparent. When an agreement comes under pressure it tends to fall apart, yet where such pressure is exerted government has to make difficult decisions. If government depends entirely upon an accommodation with a sectional interest, it is vulnerable. Due to external pressures, the goverment was forced to cut public expenditure and to take demand out of the economy. This was a result of powerful sectional interests operating in the financial markets. ${ }^{98}$ Government was seen to be reneging on its obligations under the Social Contract. In these difficult conditions, the government was unable to agree on an appropriate level of pay increases with the TUC. The Social Contract became an economic impasse. The state reverted to the language of intervention and control.

The government tried to impose pay norms, and the courts restricted the immunities of trade unions in respect of industrial action. ${ }^{99}$ In the autumn of 1978 , it was expected that the government would seek a new electoral mandate in order to get the Social Contract back on course. It failed to do so, raising the suspicion that it had lost touch with reality. During the winter, the tension between government and organised labour resulting from pay policy exploded into a "winter of discontent." The authority of the government, already tenuous because of the lack of a parliamentary majority, crumbled.

The Social Contract was, in a sense, the high water mark of the concept of abstentionism. Certainly, it involved a very close and direct relationship between

95. For an account of and views on this period see Arnold, supra n.18., ch.4.

96. Section 2(1).

97. E.g., Employment Protection Act 1975; Trade Union and Labour Relations Act 1974; Trade Union and Labour Relations (Amendment) Act 1976; Sex Discrimination Act 1975; Race Relations Act 1976; Employment Protection (Consolidation) Act 1978.

98. Interests that were arguably vindicated by the intervention of the International Monetary Fund.

99. Especially the Court of Appeal while Lord Denning was the Master of the Rolls: see, e.g., B.B.C. v. Heam [1977] 1 W.L.R. 1004 and Express Newspapers v. McShane [1979] 1 W.L.R. 390. (H.L.). of. McShane v. Express Nemspapers [1979] I.R.L.R. 79 (C.A.). 
the government and organised labour, but the relationship was to be regulated by negotiation and bargain rather than by law. To that extent, it was the antithesis of Taff Vale, Osborne and the Industrial Relations Act 1971. In another sense, however, the Conservative and Labour governments of the early 1970s had a similar vision. Both believed in economic policy through the consent of sectional interests. There is evidence that, on the whole, the trade unions and the Heath government had the beginnings of a fruitful relationship. ${ }^{1}$ If the Industrial Relations Act had been given a chance, it might have become the basis of a kind of social contract or tripartism, involving government, capital and labour. The Labour government wanted the same kind of relationship, but set about creating it in a different way, without law, because of the experience of the $1960 \mathrm{~s}$ and its 'special relationship' with the unions. It is arguable that the story of the early 1970 s is the story of two attempts to build a 'corporate' state, based on the positive agreement of national and sectional interests. The first attempt was legalistic. It failed. The second was abstentionist. It failed too. The relationship between the state and trade unions was in a state of crisis.

\section{The $1980 \mathrm{~s}-$ a new approach?}

During the 1979 election campaign, James Callaghan instructed the electorate that:

"The question you will have to consider is whether we risk tearing everything up at the roots." 2

Apparently, some Conservatives were unimpressed by the corporatism and collectivism of the 1970s. It was their intention to discard them. Plainly, this would profoundly affect the relationship between the trade unions and the state, such as it was. The new Prime Minister and her advisors believed that there was little point in seeking consensus with the unions in the traditional sense. However, there seems to have been a desire to change the union-government relationship into one of "positive partnership". ${ }^{3}$ The question was, how to go about making that change. The new government, after winning yet another general election fought on the issue of union power, promised measured legal intervention in industrial relations and in the internal affairs of trade unions. Some elements in the Conservative Party were anxious not to plunge into a 'root and branch' reform of the kind that had been attempted in the early 1970 s.

The three Conservative governments that have held office since 1979 have approached the perceived 'problem' of trade union power in two basic ways.

First, they have used economic policy. In the early 1980s the government confronted inflation by attempting to control the money supply. Initially, this deepened an existing world recession. High interest rates and a strong currency

1. See, supra, n.92.

2. Quoted in Young, supra n.94, p.131.

3. Ibid., p.116. 
made it hard for British industry to compete abroad, and suppressed demand at home. Because of this, industry shed labour. It has already been noted that when demand for labour is weak, the power of organised labour is reduced. In this climate, the problems of the 1970 s were unlikely to recur, or at least to have the same effects. It is questionable whether the decline in the power of the unions was an intended or an unintended consequence of broader economic policy. It may be that it was simply a welcome by-product. Thus, the relationship between the state and organised labour was regulated, not by statute and judicial decisions, but by the more mercurial laws of economics.

Secondly, the Conservative government has approached its relationships with the unions through legislation. There have been four major Acts of Parliament, and a fifth may be expected very soon.

The first was the Employment Act 1980. As well as restricting trade union immunities in respect of industrial action, ${ }^{4}$ the 1980 Act reintroduced Donovan's idea of a legally enforceable right to trade union membership. Initially, the right not to be unreasonably excluded or expelled from a union applied only in limited circumstances, i.e. where a Union Membership Agreement was in operation. ${ }^{5}$ Like Donovan, "In Place of Strife", and the Industrial Relations Act 1971, this represents state intervention in the internal affairs of unions. It reflects the individualistic conception of trade union government preferred by lawyers as demonstrated in, for example, Lord Denning's dissenting judgments in Breen v. $A E U^{6}$ and, after the 1980 Act, in Cheall v. $A P E X^{7}$

The second major legislative development was the Employment Act 1982 which has the effect, inter alia, of limiting the legality of union recognition requirements. ${ }^{8}$ Conceptually, the Acts of 1980 and 1982 echo the idea of the Unfair Industrial Practice, which was a central feature of the Industrial Relations Act.

The Trade Unions Act 1984 was the most direct legal intervention in the internal affairs of unions since 1971. Most importantly, the Act requires that trade unions ballot their members before instructing them to take industrial action. ${ }^{9}$ Again, this echoes "In Place of Strife" and the 1971 Act. However, while earlier proposals and enactments required that this obligation should be enforced by government, the 1984 Act approached the problem of enforcement by a more indirect route. The absence of a ballot would deprive the union of immunity against any tortious liability that might arise from industrial action. ${ }^{10}$ Such liability could only be imposed at the suit of the victim of tort. In most cases, this would be the employer with whom the union was in dispute. Thus, the state provides a legal framework for those who wish to use it, but distances itself from the responsibility,
4. Section 17.
5. Section 4.
6. [1971] 2 Q.B. 175.
7. [1983] Q.B. 126.
8. Section 12.
9. Sections 10 and 11 .
10. Section $10(1)$. 
and political minefield, of enforcement. Here, the old distinction between legalism and abstentionism seems to blur. Parliament defines legal norms, but their application is left to the participants in the process of industrial relations who may, or may not, choose to go to court. The 1984 Act also requires that all members of a trade union's permanent executive committee should be elected by secret ballot. ${ }^{11}$

The Employment Act 1988 repeats and extends the theme of the 1984 Act. The express aim of both Statutes was, and is, to enhance the power of individual trade union members and to make union government accountable to those whom it exists to serve. ${ }^{12}$ The 1988 Act tightens the requirements of election of the Permanent Executive Committee, ${ }^{13}$ and gives individual members the right to force a pre-industrial action ballot, through the courts, ${ }^{14}$ and of inspecting the union's accounting records. ${ }^{15}$ Very importantly, the Act builds upon the Employment Act 1980 by giving every trade union member the right not to be unjustifiably disciplined. ${ }^{16}$ This is not restricted to members who are covered by a Union Membership Agreement. Nor is the concept of "discipline" restricted to exclusion or expulsion as it was in 1980. Also, while the concept of unreasonable exclusion or expulsion in the 1980 Act was largely undefined, ${ }^{17}$ the 1988 Act defines a number of circumstances in which disciplinary action will be deemed to be unjustifiable. These include discipline for failure to support industrial action, even if such action has been approved by ballot, and disciplinary action for suggesting that there is impropriety in union government, unless that suggestion is made in bad faith. ${ }^{18}$ In addition, a union member who wishes to use the legal system to protect these rights may seek the assistance of a new Commissioner for the Rights of Trade Union Members. ${ }^{19}$

The Employment Act 1988, and by implication the Trade Union Act 1984, has been criticised as "an objectionable intervention in trade union affairs". ${ }^{20}$ Yet it is notable that the legislation of the 1980 s, though radical, is largely enforceable at the suit of private persons - employers and individual trade union members. Unlike "In Place of Strife" and the Industrial Relations Act, there are few new regulatory powers in the Secretary of State for Employment. Indeed, it has been

\section{Section 1.}

12. Trade Unions and their Members: Cmnd. 95 (1987).

13. Section 12.

14. Section 1.

15. Section 6.

16. Section 3.

17. Except by reference to codes of practice issued periodically by the Secretary of State for Employment.

18. Section 3(3).

19. Sections 19 and 20. The first case brought with the assistance of the Commissioner came before the High Court on 26 June 1989 in the form of an application for an order to restrain industrial action by the N.U.R. because of the allegedly defective conduct of the required ballot. The application was rejected.

20. McKendrick, (1988) 17 I.7.L. 141. 
suggested that that office may face abolition in the near future. ${ }^{21}$ There are no new statutory bodies, with the exception of the Commissioner for the Rights of Trade Union Members, and no new courts. Thus, although the law has been reintroduced into industrial relation's on a scale that has not been seen since 1971, the government is careful to distance itself from the application of the law which, it seems, is the responsibility of the individuals and organisations that are affected by it, and it is the individual that is emphasised most. The philosophies of legalism and abstentionism seem to be finely balanced, and there is a deafening silence as to the nature of the relationship between trade unions and the state. By all accounts, they now have very little to do with each other. ${ }^{22}$

In the late 1980s, the very idea of collective bargaining in the traditional, industry-wide sense, seems to be under review and the courts are involved in industrial conflict on a day-to-day basis. However, it is far from clear that this is resulting in lower wage demands. As the economy overheats, and inflation returns, some of the industrial problems of the 1970 s seem to be returning. By the end of the decade it should be possible to make a preliminary judgment about the efficiency of the new legal framework, as it is tested by resurgent industrial conflict.

There is one aspect of legal development in the 1980 s that is very striking. It is the way in which, by increments, the broad policy of "In Place of Strife" and the Industrial Relations Act 1971 has been implemented without the foundations of the constitution being shaken. Trade unions, which never wished to exist as corporate bodies, are now treated as if they were by the 1984 and 1988 Acts, in spite of the protestations of section 2 of the Trade Unions and Labour Relations Act $1974 .{ }^{23}$ Ballots must be held on a wide range of occasions. The policy of legalism has been installed while ministers fastidiously maintain their distance. What is remarkable is that this has become a rare subject of political consensus. ${ }^{24}$ In a sense, it is at least arguable that Taff Vale, Osborme, "In Place of Strife" and the Industrial Relations Act have been vindicated. It is even possible that they never ever went away, and that the Social Contract was the aberration in the story. Will the next stage be a movement towards 'positive' partnership?

21. Though it has been suggested by the Secretary of State for Employment that he may present a bill designed to restrain strikes in essential public services.

22. On 28 June 1989, the then Secretary of State for Transport declined to intervene in the current railway dispute, on the basis that it was for management and labour to resolve their own differences. This may be inconsistent with the suggestion in $n .21$, supra.A similar view has been taken in the context of the ambulance workers' work to rule' of autumn/winter 1989.

23. Indeed, McKendrick, supra n.20, compares the provisions of the Employment Act with the model 'Table A' articles of association in the Companies Act 1985.

24. In that even the Labour Party is not publicly committed to the repeal of all the labour relations legislation of the 1980s. 


\section{Conclusion}

As an historical survey all that has been said can only scratch the surface of the long and complex development of collective labour law, but at the same time it is possible to see the begining of some historical patterns. First, it appears that trade union legislation has been as much the product of concern about the relationship between public and sectional interests as of a desire to influence the operation of the labour market. In fact there seems to be little evidence of a preoccupation with industrial relations as such. On the whole, it seems that there has been more interest in minimising the wider consequences of poor labour relations on the economy and of trade union power on the ability of government to govern according to its own perception of the public interest. At one extreme, the Combination Acts of 1799 and 1800 present a particularly crude example of all of this and while the Trade Union Acts of 1871 and 1876 denote an important change of attitude the law that they contained turned out to be as much about legal control of trade unions as they were about liberalisation. More subtly, "In Place of Strife", its successor the Industrial Relations Act 1971 and the Social Contract all reflect, in different ways, a preoccupation with the need to govern effectively while bearing in mind the views and the power of organised labour. Taken at face value, the legislation of the $1980 \mathrm{~s}$ seems to have less to do with these preoccupations in the sense that the unions seem to have been excluded from the corridors of power to the extent that government does not consider itself to have an important relationship with them at all. However, it is far from clear that this legislation should be taken at its face value. In any event, the lessons of history may show that the abstentionist view of industrial relations is destined to continuing disappointment.

The second interesting pattern reflects the way in which the concerns of the 1960 s and 1970s remain the concerns of the 1980s and the striking homogeneity of the legislative approach to them. The early ideas of the Donovan Commission which were reflected in "In Place of Strife" and the 1971 Act have been vindicated in recent legislation to an extent that is surprising. Many of Donovan's proposals which were so controversial at their inception are now firmly entrenched in the law, in substance if not in form. In that context, the Social Contract of 1974 to 1978 may be seen either as an historical aberration or as an attempt to formalise an idealised view of the pre-Donovan period. It was certainly an attempt to place relations between the state and collective bargaining on to a secure footing. Like most other attempts, it was hardly an unqualified success.

The history of trade union law in Britain has been unhappy and confused and that fact alone may be a sufficient reason for taking the traditional abstentionist view. As a theory it has certainly contributed more to British industrial relations scholarship than any other. But history seems to indicate that it has always operated as a hope or value judgment rather than as a description. Even during its supposed heyday, as an official policy the spectre of legalism haunted the feast, always ready to return if the industrial relations system and therefore the state 
came under pressure. Now it has returned with a vengeance. It was probably knocking on policy makers' doors as early as the late 1950s. It is unlikely to leave in the near future and it is hard to be sure that it ought to. As it stands, a pause for thought and sensible rationalisation and codification seem to present the best hope for clarity of underlying principle and for a praiseworthy "phase VI" in the curious history of collective labour law. 